\title{
Life history and production of a cold-temperate population of the sublittoral amphipod Ampelisca araucana
}

\author{
Franklin D. Carrasco and Dagoberto F. Arcos \\ Departamento de Oceanología, Universidad de Concepción, Casilla 2407, Concepción, Chile
}

\begin{abstract}
A study was made of the population dynamics and production of the amphipod Ampelisca araucana Gallardo on the continental shelf off the central coast of Chile. The species is semi-annual, with breeding extending throughout the year. Two maximum periods of reproductive activity occurred in December-January and May-July. Recruitment began in December-January and July. Females produced 1 brood, in some cases probably 2. Both females and males lived for a maximum of 7 to $7.5 \mathrm{mo}$. Secondary production of $A$. araucana from October 1976 to October 1977 was 8.03 to $12.43 \mathrm{~g}$ dry weight $\mathrm{m}^{-2} \mathrm{yr}^{-1}$ with an annual turnover ratio of 3.65 to 4.45 . The figures produced by the cohort summation of losses, integration from the Allen curve, instantaneous growth rate, and size-frequency methods are similar both in range and magnitude, with the exception of the constant $\mathrm{P}: \mathrm{B}$ ratio approach. These values are the highest so far reported for a sublittoral amphipod. This fact could be explained in connection with coastal upwelling processes, reported to occur frequently, during summer, off the coasts of North and Central Chile. An important part of the A araucana production is probably consumed by demersal fishes such as hake and jack-mackerel.
\end{abstract}

\section{INTRODUCTION}

Growth and production of the most abundant species of benthic macro-infauna in an area off the coast of Concepción, Chile, have been investigated since 1976 (Carrasco and Arcos, 1980). The studies focussed on possible effects on the benthos of the high productivity of surface waters, mainly due to coastal upwelling processes, under the influence of anticyclonic winds, associated with a high-pressure cell centered in the South Pacific Ocean. The cell is displaced to the North in winter and to the South in summer, producing seasonal variation of winds in the littoral area. Winds, therefore, are predominantly northerly during winter and southwesterly in summer. The main hydrographic characteristics in the offshore area adjacent to Concepción Bay is clearly affected by an upwelling process during periods of southwesterly winds (Brandhorst, 1971; Ahumada and Chuecas, 1979; Arcos and Wilson, 1983). In general, the surface Humboldt coastal water, which is sub-antarctic (SAAW) in origin, flows northward along the coast, and it belongs to the large-scale wind-driven anticyclonic circulation of the southeast- ern Pacific Ocean. Below the SAAW, the equatorial subsurface water (ESSW) flows southward and is characterized by a very low concentration of dissolved oxygen (<1 ml O $\mathrm{ml}^{-1}$ ) (Gunther, 1936; Brandhorst, 1971). The minimum oxygen layer (ESSW) is usually found off Concepción Bay around the continental shelf break; during summer, when upwelling prevails, it moves up toward the shore over the shelf. This water is involved in the poleward subsurface flow, and during strong events it can be found within a few meters of the surface and within Concepción Bay (Ahumada et al., 1983). The temperature regime is characterized by a mean annual surface temperature of $12.9^{\circ} \mathrm{C}$, which ranges from $10.5^{\circ} \mathrm{C}$ in winter to $16.5^{\circ} \mathrm{C}$ in summer. Near-bottom temperatures reach minimum values in spring $\left(9.5^{\circ} \mathrm{C}\right)$ and maximum values in winter $\left(13^{\circ} \mathrm{C}\right)$ (Ahumada and Chuecas, 1979).

Ampelisca araucana Gallardo 1962 is a widely distributed, often dominant amphipod, inhabiting sublittoral sediments consisting of $>50 \%$ silt and clay, off the southwestern coast of South America in the Pacific Ocean (Gallardo, 1962, 1963, 1968; Carrasco and Arcos, 1980; Carrasco and Gallardo, 1983; W. Arntz 
and V. A. Gallardo, pers. com.). A. araucana is an important component of the diet of hake Merluccius gayi gayi Guichenot, flatfishes Paralichthys spp., rock cod Eleginops maclovinus (Valenciennes) (Gallardo, 1962) and rat-tail Coelorhynchus aconcagua Iwamoto (Meléndez, 1981).

Sublittoral species of marine amphipods for which aspects of their life history have been elucidated and their production calculated include Ampelisca spp. (Sanders, 1956), A. brevicornis (Klein et al., 1975), A. tenuicornis (Sheader, 1977), and Pontoporeia femorata (Wildish and Peer, 1981). In this study the aim was to describe some aspects of the life cycle and estimate the secondary production for a population of $A$. araucana from the continental shelf off the Chilean coast.

\section{MATERIALS AND METHODS}

All bottom samples came from 1 station, located off the Bay of Concepción, Chile $\left(36^{\circ} 35^{\prime} \mathrm{S} ; 7^{\circ} 05^{\prime} 35^{\prime \prime} \mathrm{W}\right)$, on a muddy bottom, $65 \mathrm{~m}$ deep. General oceanographic features of the area have been described by Ahumada and Chuecas (1979). Ampelisca araucana samples were taken with 4 replicate $0.1 \mathrm{~m}^{2}$ Van Veen grabs; changes within the population during 1 yr (October 1976 to October 1977) were studied by sampling 8 times. Samples were sieved through a $500 \mu \mathrm{m}$ mesh 12 " $(30.7 \mathrm{~cm})$ diameter geological sieve in a $60 \mathrm{l}$ plastic bucket using a sea-water jet floatation technique. The biological material was fixed in $10 \%$ sea water-formalin solution and stained in Rose Bengal. In the laboratory, specimens of A. araucana were picked out from samples dominated by dense, entangled macroscopic filaments of Thioploca spp., a blue-green algae typically present in benthic samples of the area (Gallardo, 1977). Amphipods were later preserved in $70 \%$ ethanol, identified, counted and dry-weighted (Crisp, 1971). A total number of 14,460 specimens of $A$. araucana were collected. The length of the amphipods was measured from the tip of the rostrum to the tip of the telson for about 500 specimens at each sampling date. Specimens were sorted into 4 categories: mature females with well developed oostegites; ovigerous females; mature males; and immature individuals. Sex ratios were tested for bias using G-tests (Sokal and Rohlf, 1969). Secondary production was estimated using several methods; these include the Allen curve (Peer, 1970), the instantaneous growth rate method (Ricker, 1946), the cohort summation of losses method (Crisp, 1971), the average cohort or size frequency method (Hynes and Coleman, 1968), and the constant $\mathrm{P}: \mathrm{B}$ ratio approach (Waters, 1977; Lapchin and Neveu, $1980 \mathrm{a}, \mathrm{b})$. The last 2 have thus far been used mainly in freshwater ecology.

\section{RESULTS}

\section{Life history and abundance}

Fig. 1 shows that abundance was highest in early spring (October 1976); included in the samples are juveniles, adults and ovigerous females. During late spring-early summer, population density fell to one half that in spring, until during mid summer density

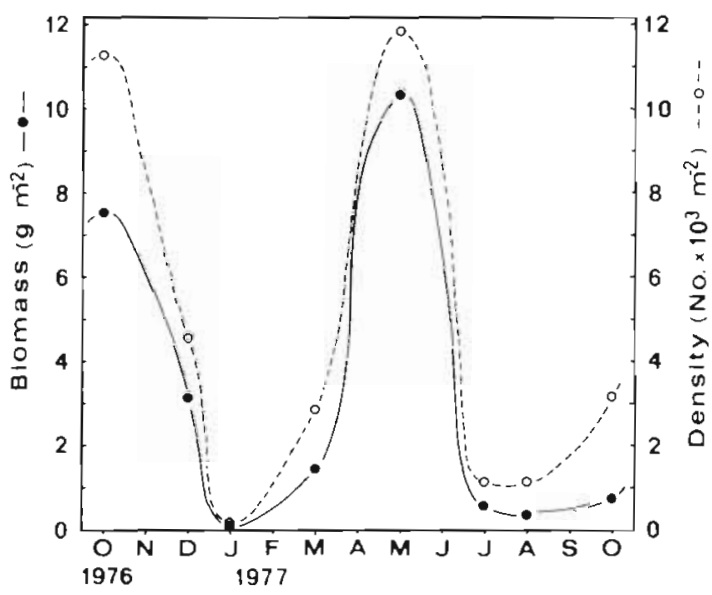

Fig. 1. Ampelisca araucana. Variations of density and standing stock values. October 1976 to October 1977

reached its lowest value of the year. In late summer, density increased, attaining a peak in autumn comparable to that in the spring. Winter densities show values as low as those in summer. Densities increased in early spring, although they remain lower than in the preceding year. The standing-stock curve shows the same pattern as that for density, with 2 peaks (spring and autumn) and 2 lows (summer and winter).

Ovigerous females were present throughout the year, although the highest breeding activity occurred in December 1976-January 1977 and May-July 1977 (Fig, 2 and 3). Individuals present in October 1976 (Fig. 3) belonged to a rapidly growing cohort (Cohort 1); the larger individuals of which matured and bred in December 1976-January 1977 giving rise to the first new generation of 1977 . The specimens of the 1976 cohort had already disappeared by March. Juveniles, which probably recruited in February-March 1977. also grew rapidly to mature mainly in the period MayJuly 1977, producing a second generation for 1977 which recruited from July onwards. This Cohort 2 had disappeared from the samples by October 1977. The second generation (referred to as Cohort 3), first appeared in July 1977 and had a long period of recruitment probably from June-July 1977 to OctoberDecember 1977. Fig. 3 also includes an important recruitment in October 1977 produced by matured 


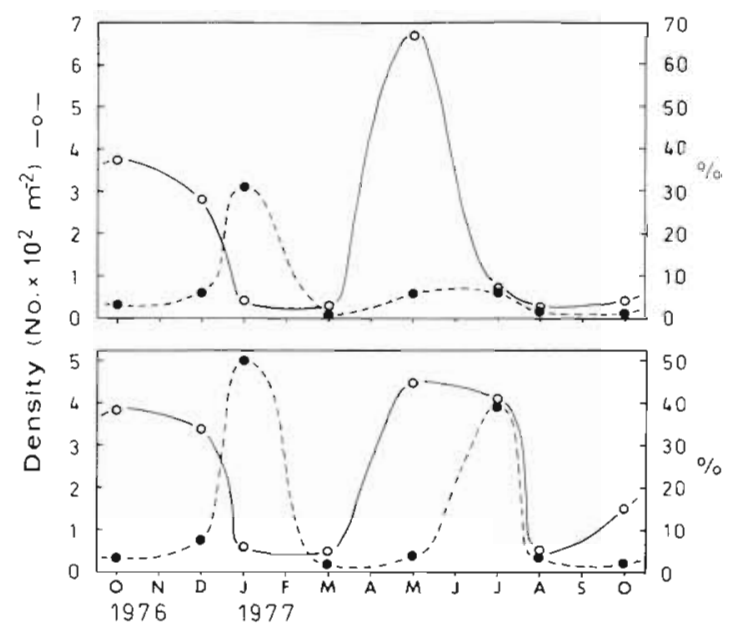

Fig. 2. Ampelisca araucana. Density and percentage of mature males and ovigerous females at study site. Upper: frequency of males within total adult population; lower: frequency of females within total adult population

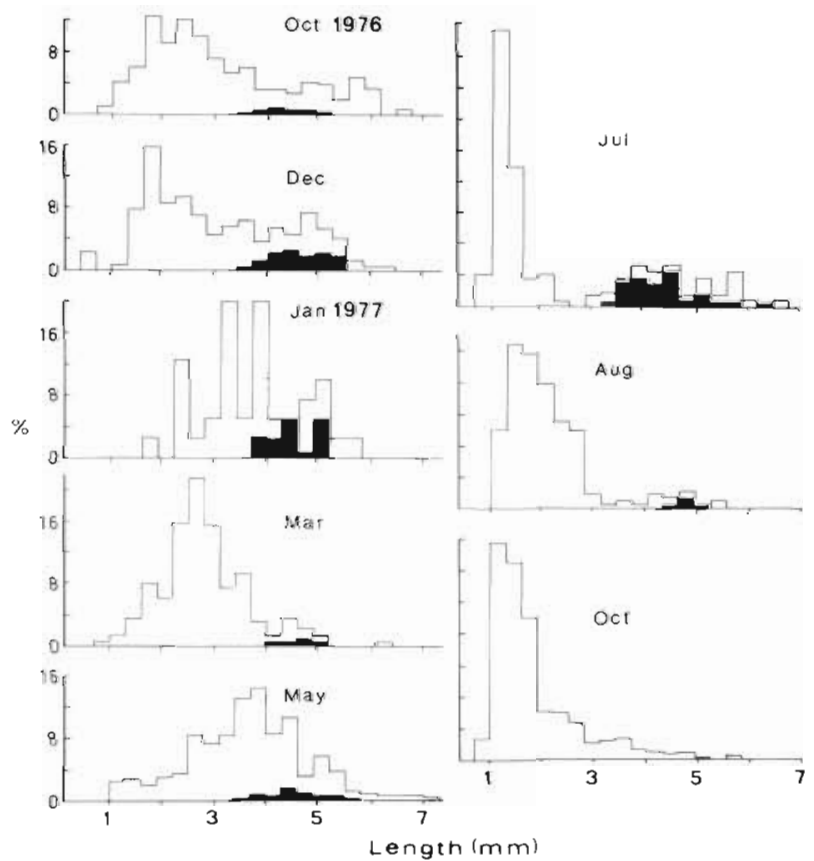

Fig. 3. Ampelisca araucana. Size-frequency distributions in samples taken between October 1976 and October 1977 Black areas: ovigerous females

females in August of the same year. From Fig. 1, 3 and 4 can be inferred that the length of the life-cycle of Ampelisca araucana, at the sampling area, is of about 5 to 7 mo for the summer generation and about 3 to 7 mo for the overwintering generation. Both sexes live for a maximum period of 7 to $7.5 \mathrm{mo}$. Females matured at a body length of 3.3 to $3.7 \mathrm{~mm}$ and reached a maximum body length of $6.3 \mathrm{~mm}$. This minimum size of reproductive females is in the range found in other ampeliscids (Nelson, 1980). Maximum body length for males was $7.2 \mathrm{~mm}$. Determination of time or size-frequency category when males first matured was not possible, due to difficulties in recognizing clearly between juvenile and adult males. There was no evidence to postulate the presence of a pelagic $A$. araucana male.

The number of eggs per brood $(\mathrm{Y})$ was related to the body length of females (L) by the regression equation $\mathrm{Y}=0.86 \mathrm{~L}+0.55(\mathrm{r}=0.30, \mathrm{n}=34)$. The poor correlation resulted from small size-class numbers or the small range of sizes of ovigerous females encountered, the low numbers of these counted, the loss of eggs through handling (washing and sieving of benthic samples), or a combination of these factors. Nevertheless, the linear relationship found lies within the range and fits well with data for shallow-water or estuarine infaunal gammarid amphipods obtained by Van Dolah and Bird (1980). Mean diameter of Ampelisca araucana eggs is $452 \pm 41 \mu \mathrm{m}(\mathrm{n}=20)$; the most advanced stage of embryonic development, prior to hatching, was $0.75 \mathrm{~mm}$ in length. However, the eggs of A. araucana are smaller than those of boreal ampeliscids (Wildish, 1982).

\section{Production estimates}

The variations in total density (Fig. 1), density and percentage of both sexes (Fig. 2), length-frequency histograms (Fig. 3) and recruitment-mortality growth curves (Fig. 4) for October 1976 to October 1977, show 3 cohorts for the Ampelisca araucana population. Cohort 1, part of the 1976 summer generation, first appeared in October and remained in the population until March 1977. Cohort 2 (the overwintering generation) recruited in February-March 1977 and disappeared by September 1977. Cohort 3 (the first part of the summer generation) began its recruitment in July 1977 and grew until October 1977. Fig. 4 shows for each cohort, by means of survivorship and growth

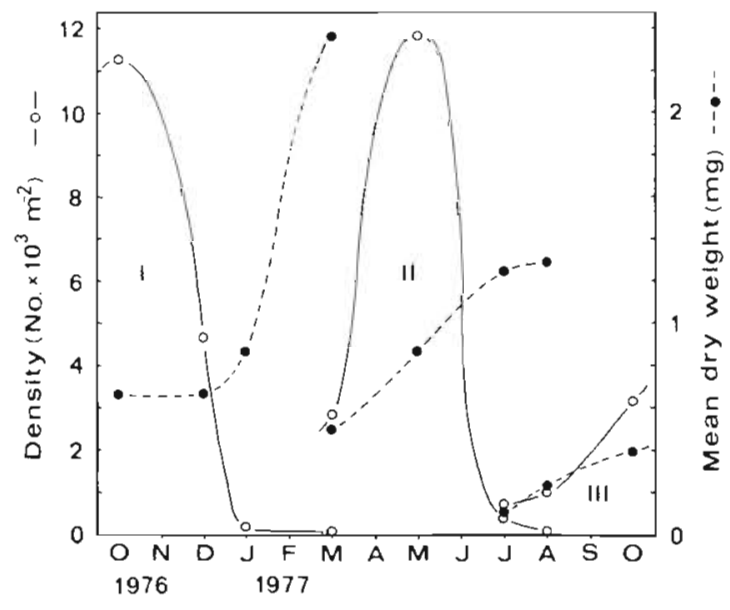

Fig. 4. Ampelisca araucana. Recruitment-mortality growth curves for each cohort. October 1976 to October 1977 
Table 1. Ampelisca araucana. Cohort production estimates for the population off Concepción, Chile, 1976-1977

\begin{tabular}{|c|c|c|c|c|c|c|}
\hline Cohort & Month & $\begin{array}{l}\text { No. in } \\
\text { cohort } \\
\mathrm{Nm} \mathrm{m}^{-2}\end{array}$ & $\begin{array}{l}\text { Mean weight } \\
\bar{w}(\mathrm{mg})\end{array}$ & $\begin{array}{c}\text { Weight } \\
\text { increment } \\
\Delta \bar{w}(\mathrm{mg})\end{array}$ & $\begin{array}{l}\text { Mean number } \\
\quad \text { per } \mathrm{m}^{2} \overline{\mathrm{N}}\end{array}$ & $\begin{array}{l}\text { Production } \\
\text { increment } \\
\bar{N} \Delta \bar{w} \text { (mg) }\end{array}$ \\
\hline \multirow{5}{*}{1} & Aug & $(1,500)$ & $(0.2340)$ & - & - & - \\
\hline & Oct & 11,270 & 0.6671 & 0.4331 & 6,387 & $2,766.21$ \\
\hline & Dec & 4,650 & 0.6734 & 0.0063 & 7,960 & 50.15 \\
\hline & Jan & 133 & 0.8786 & 0.2052 & 2,392 & 490.84 \\
\hline & Mar & 12 & 2.3700 & $(1.4815)$ & $(73)$ & $(108.15)$ \\
\hline \multirow{4}{*}{2} & Mar & 2,845 & 0.4987 & - & - & - \\
\hline & May & 11,820 & 0.8732 & 0.3745 & 7,333 & $2,746.09$ \\
\hline & Jul & 390 & 1.2544 & 0.3812 & 6,105 & $2,327.23$ \\
\hline & Aug & 75 & 1.2913 & 0.0369 & 233 & 8.60 \\
\hline \multirow{3}{*}{3} & Jul & 730 & 0.1245 & - & - & - \\
\hline & Aug & 1,060 & 0.2281 & 0.1036 & 895 & 92.72 \\
\hline & Oct & 3,165 & 0.2394 & 0.0113 & 2,113 & 23.88 \\
\hline \multicolumn{7}{|c|}{$\begin{array}{l}\text { Total production }=8,505.71 \mathrm{mg} \mathrm{m}{ }^{-2} \mathrm{yr}^{-1} \\
\text { Mean biomass } \overline{\mathrm{B}}=2,046.86 \mathrm{mg} \\
\text { Production/biomass ratio }=4.16\end{array}$} \\
\hline
\end{tabular}

curves, changes in density and growth of individuals, expressed as the variation in mean dry weight between samples. These figures will be used to estimate secondary production by the different methods.

\section{Cohort summation-of-losses method}

Computation (Table 1) is based on 'Method 2' of Crisp (1971) for stocks with recruitment and age separable by means of the following equation:

$$
\mathrm{P}=\sum_{\mathrm{t}=0}^{\mathrm{t}=1} \mathrm{G}_{\mathrm{i}} \mathrm{w}_{\mathrm{i}} \Delta_{\mathrm{t}}
$$

where time $\mathrm{t}=1 \mathrm{yr} ; \mathrm{G}_{\mathrm{i}}=$ mean instantaneous growth rate of an individual of $w_{1}$ weight. Values in parentheses correspond to corrections made during computation of Cohort 1 , since the maximum value of density was obtained in October 1976; it was thus necessary to adjust to a previously assumed date of sampling in order to avoid a significant underestimation of cohort production. The average standing-stock $(\bar{B})$, for the sampling period at the studied station is $2,046.86 \mathrm{mg}$ $\mathrm{m}^{-2}$. Cohort 2, the overwintering generation, shows the highest production value of $5,081.92 \mathrm{mg} \mathrm{m}^{-2} \mathrm{yr}^{-1}$, and the total estimated production is of $8,505.71 \mathrm{mg}$ $\mathrm{m}^{-2} \mathrm{yr}^{-1}$, with a $\mathrm{P} / \overline{\mathrm{B}}$ ratio equal to 4.16 .

\section{Allen curve method}

This method is based on Peer (1970) and Wildish and Peer (1981). For each generation an Allen curve was eye-fitted between the points determined by densities with the corresponding mean dry weights of individuals. Production is integrated below the generated curves by planimetry. Total estimated production through this method is $8,031 \mathrm{mg}$ dry weight $\mathrm{m}^{-2} \mathrm{yr}^{-1}$; mean biomass for the sampling period is $\overline{\mathrm{B}}=2,201.03 \mathrm{mg}$, and $\mathrm{P} / \overline{\mathrm{B}}=3.65$.

\section{Instantaneous growth-rate method}

This method was developed by Ricker (1946) and Allen (1949), and modified by Lapchin and Neveu (1980a). It estimates production as follows:

$$
P=\sum_{i} G_{i}\left\langle B_{i}\right\rangle
$$

where $G_{i}=$ instantaneous growth rate

$$
\mathrm{G}_{\mathrm{i}}=\ln _{\overline{\mathrm{p}}_{\mathrm{i}+1}}-\ln _{\overline{\mathrm{p}}}
$$

and $B_{i}=$ mean biomass between time $t_{1}$ and time $t_{i+1}$

$$
\left\langle B_{i}\right\rangle=\frac{N_{i} \bar{p}_{1}+N_{i+1} \bar{p}_{i+1}}{2}
$$

Production is computed for each generation in order to avoid overestimation of total production (Table 2). Cohort 2 (the overwintering generation) shows the highest production value, $5,255.19 \mathrm{mg} \mathrm{m}^{-2} \mathrm{yr}^{-1}$ with a total production of $8,306.10 \mathrm{mg} \mathrm{m}^{-2} \mathrm{yr}^{-1}$ and a $\mathrm{P} / \overline{\mathrm{B}}$ ratio of 4.41 .

\section{Size-frequency method}

Also known as the average-cohort of Hynes method, it has been used extensively in freshwater biology and 
Table 2. Ampelisca araucana. Computation of secondary production by the instantaneous growth rate method, 1976-1977

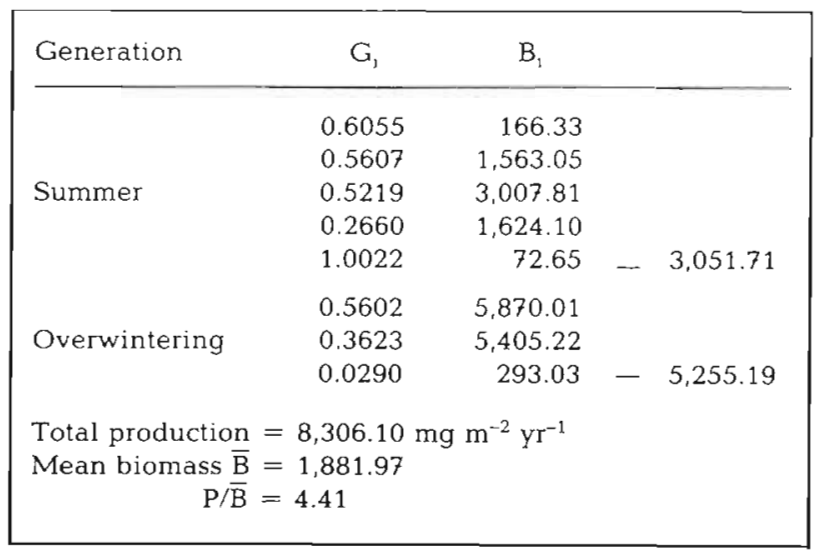

recently in marine biology (Wildish and Peer, 1981). Introduced by Hynes (1961), it was later modified by Hynes and Coleman (1968), Hamilton (1969), Neveu (1977), Benke (1979), Lapchin and Neveu (1980a, b), and Menzie (1980). The secondary production estimate for Ampelisca araucana was computed following Lapchin and Neveu (1980b), where the value of production obtained through Hynes or Hamilton methods, was corrected by multiplying the result by the mean number of length classes that contain observations (Neveu, 1977; Lapchin and Neveu, 1980b). Values are given in Table 3 where total production is $9,791.80 \mathrm{mg}$ $\mathrm{m}^{-2} \mathrm{yr}^{-1}$, mean annual biomass $2,201.03 \mathrm{mg}$, and the $\mathrm{P} / \overline{\mathrm{B}}$ ratio 4.45 .

\section{Constant $\mathrm{P}: \mathrm{B}$ ratio approach}

This is a quick method, requiring neither counting nor individual measurements, but instead an adequate knowledge of the life-cycle. According to Neveu (1977), Waters (1977), and Lapchin and Neveu (1980a, b) this approximation provides a good estimate of secondary production. In accordance to several authors (see Lapchin and Neveu, 1980b), a P/B ratio per cohort constant near to 4 can be utilized to estimate secondary production, and then

$$
P_{j}=4 \times n_{j} \times B_{j},
$$

where $\mathrm{n}_{\mathrm{j}}=$ generations per year of the species $\mathrm{B}_{\mathrm{j}}=$ annual mean biomass. The last term must be corrected to

$$
B_{j}^{\prime}=B_{j} \times\left(12 / m_{j}\right),
$$

where $\mathrm{m}_{\mathrm{j}}=$ total length (in mo) of the cohort durations (Lapchin and Neveu, 1980b), which is equivalent to the use of the cohort production interval (CPI), suggested by Benke (1979) for the size-frequency method. Sec- ondary production of Ampelisca araucana by this method is thus

$$
\begin{aligned}
\mathrm{P}_{\mathrm{j}} & =4 \times \mathrm{n}_{\mathrm{j}} \times \mathrm{B}_{\mathrm{j}}[12 /(6+7+4)] \\
& =4 \times 2 \times 2,201.03(0.706) \\
& =12,429.35 \mathrm{mg} \mathrm{m}^{-2} \mathrm{yr}^{-1}
\end{aligned}
$$

\section{DISCUSSION}

Quantitative benthic sublittoral data obtained from the Concepción Bay region have shown Ampelisca araucana to be one of the most abundant species (Gallardo, 1968; Carrasco and Arcos, 1980; Carrasco and Gallardo, 1983). The present study documents for $A$. araucana at the study site a life cycle of ca. 7 mo. Such a semi-annual life cycle is not in line with the reproductive cycle typical for a sublittoral amphipod (Wildish and Peer, 1981). However, it parallels the life cycle of the littoral and shallow-water A. diadema, A. spinipes, and $A$. tenuicornis (Sanders, 1956) and of the littoral species A. vadorum and A. abdita (Mills, 1967).

Recruitment of the summer generation appears to coincide with the temperature maximum reached by the bottom water at the study area in July (ca. $13^{\circ} \mathrm{C}$ ). The overwintering generation is thought to be induced by the increase in bottom temperature that follows the lowest temperatures in spring $\left(9.5\right.$ to $\left.10.5^{\circ} \mathrm{C}\right) . A$. araucana would experience the highest minimum temperature of any subtidal amphipod population so far sampled (Wildish, pers. comm.), and above the breeding threshold temperature of $9.5^{\circ} \mathrm{C}$ at all times of the year. The large numbers of amphipods encountered in October 1976 coincide with the spring phytoplankton bloom, and the May values result from a latesummer secondary peak in phytoplankton (Rivera, 1968).

The problem of sex identification in Ampelisca has been discussed by Sanders (1956), Mills (1967) and Hastings (1981). In this study, identification was only possible for the largest size classes, and only for mature and ovigerous females and subadult males. Within these classes a biased sex ratio was found. Sometimes with an excess of mature and ovigerous females (G-test, $G_{t}=402$, d.f. $=8, P>0.005$ ) or, on some sampling dates, to mature males (G-test, $G_{H}=364$, d.f. $=7, P>0.005$ ). This situation, i.e. a sex ratio which varies temporally, has been reported for other invertebrates (Wildish, 1977), and for $A$. araucana would be explained by differential male/ female mortality which varies with the time of year. It has been reported in the literature that the sex ratio for Amphipoda is significantly biased to females, a fact explained by the drastic fall in numbers of males 
Table 3. Ampelisca araucana. Computation of secondary production by average-cohort method

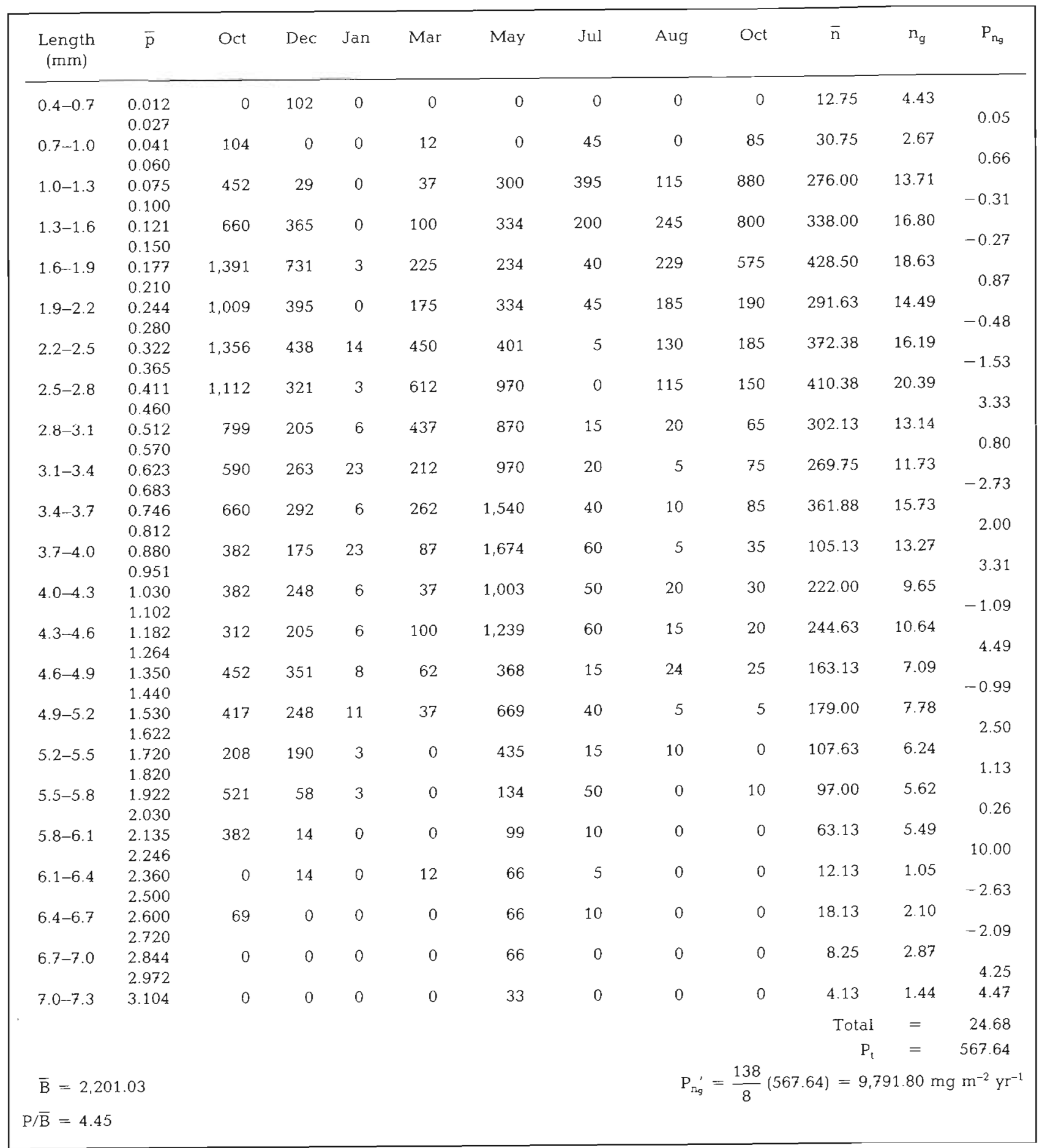

which metamorphose, copulate and die (Kanneworf, 1965; Mills, 1967; Klein et al, 1975; Sheader, 1977; Hastings, 1980). For A. araucana it may be suggested that either some females produce 2 broods or that some adult males persist a longer time, compared with the majority of the numbers of their cohort, as altemative hypotheses to explain the fast growth which can be observed from the corresponding curves.

For each generation the same features are shown by the survivorship (recruitment) curves, i.e. an initial high rate of population density increase until a maximum value is reached (ca. 11,000 to 12,000 indiv. 
$\mathrm{m}^{-2}$ ): subsequently, there is a decrease in population density due to heavy mortality, probably mainly by predation, and finally a minimum value is attained represented by senescent adults. The semi-annual life history of Ampelisca araucana is well explained by the statement of Wildish (1982), which considers these life histories influenced by predation pressure. It is believed that $A$. araucana is heavily predated by demersal fish (Gallardo, 1962; Meléndez, 1981), and recent observations indicate predation by jack mackerel (Trachurus murphyi Nichols), the second most important species in the fishery of Chile with landings of more than $1 \times 10^{6} \mathrm{t}$ in 1981 (SERNAP, 1981).

Methods used to estimate secondary production of Ampelisca araucana resulted in similar figures, both in range and magnitude, i.e. from $8.03 \mathrm{~g}$ dry weight $\mathrm{m}^{-2}$ $\mathrm{yr}^{-1}$ to $9.79 \mathrm{~g} \mathrm{~m}^{-2} \mathrm{yr}^{-1}$, with the exception of the result obtained through the constant P:B ratio approach, which significantly overestimates production. A. araucana production values as estimated in this study are the highest so far reported for a sublittoral amphipod population. Thus, Cederwall (1977) reported 3.2 and $3.0 \mathrm{~g}$ dry weight $\mathrm{m}^{-2} \mathrm{yr}^{-1}$ for Pontoporeia affinis and $P$. femorata, respectively; Wildish and Peer (1981) found 11.06 to $13.61 \mathrm{~g}$ wet weight $\mathrm{m}^{-2}$ $\mathrm{yr}^{-1}$ for a Canadian population of $P$. femorata; Sheader (1977) reported $0.103 \mathrm{~g}$ ash-free dry weight as secondary production, and Klein et al. (1975) recorded $4.0 \mathrm{~g}$ wet weight $\mathrm{m}^{-2} \mathrm{yr}^{-1}$ for $A$. brevicornis.

Values higher than, or in the range of, those reported in this paper have been found for some littoral or estuarine amphipod populations. Thus, Birklund (1977) obtained a production value of $8.37 \mathrm{~g}$ dry weight $\mathrm{m}^{-2} \mathrm{yr}^{-1}$ for Corophium insidiosum (his Sta. 6). He cites Casabianca who found $60.0 \mathrm{~g}$ dry weight $\mathrm{m}^{-2}$ $\mathrm{yr}^{-1}$ for the same species in Corsica. The differences were explained in particular by the higher temperature of this Mediterranean island. Mossman (1978) computed a production value of $13.40 \mathrm{~g} \mathrm{C} \mathrm{m}^{-2} \mathrm{yr}^{-1}$ and a $\mathrm{P} / \mathrm{B}$ ratio of 7.0 for an estuarine Corophium volutator population.

The production: biomass (turnover) ratio of Ampelisca araucana at the sampling station ranges, according to the method used, from 3.65 to 4.45 . This range is within that found for other sublittoral populations, e.g. P. femorata, with $\mathrm{P} / \mathrm{B}$ ratios of 3.64 to 4.78 (Wildish and Peer, 1981). Klein et al. (1975) found, from monthly samples of $A$. brevicornis, a $\mathrm{P} / \mathrm{B}$ ratio of about 4.0; Sheader (1977) reported a ratio of 3.4 for $A$. tenuicornis, and Sanders (1956) a ratio of 5 for Ampelisca species A.

If production values obtained by integration below the Allen curves (Lapchin and Neveu, 1980b) are taken as reference, it can be seen that the cohort summation of losses and the instantaneous growth rate methods give closely related results, while the size-frequency method yields an overestimation (ca. $20 \%$ ) over the above-mentioned values. The constant $\mathrm{P}: \mathrm{B}$ ratio method reveals an overestimation of about $50 \%$ for $A$. araucana. Nevertheless, the latter produces an acceptable figure considering the advantages of speed offered by this method. The simplest appears to be the calculation of the area under an approximated Allen curve, with the advantage that it limits the variation due to sampling incidence (Lapchin and Neveu, $1980 \mathrm{~b}$ ). Independent of the method used, the main prerequisites for any production computation are adequate knowledge of the life history of the species, especially the voltinism; data on cohort intervals (Waters, 1979); and the frequency of sampling in relation to cohort generation time (Lapchin and Neveu, $1980 \mathrm{~b})$.

The high values of production reported here for Ampelisca araucana, together with those given for the

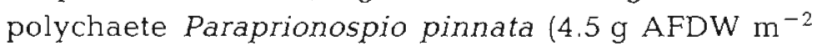
$\mathrm{yr}^{-1}$ ) (Carrasco and Arcos, 1980), and the high standing-crop of the prokariont mats of Thioploca spp. (Gallardo, 1977), suggest that the sublittoral benthos off central Chile, an area of coastal upwelling, is a highly productive system.

Acknowledgements. We deeply thank Drs. D. J. Wildish, S. A. Gerlach, and 2 anonymous reviewers for critical reading and improvement of our manuscript. Dr. V. A. Gallardo read and helped prepare an earlier English version. We also thank Mr. L. Aburto for assistance; the crew of R/V 'Lund'; and Ms. $\mathrm{H}$. Prosser and S. Cisternas for typing. This work was initially funded by 'Asociación de Industriales Pesqueros de Talcahuano', Chile and by Grant No. 3.08.04 from 'Dirección de Investigación, Universidad de Concepción'

\section{LITERATURE CITED}

Ahumada, R., Chuecas, L. (1979). Algunas características hidrográficas de la Bahía de Concepción $\left(36^{\circ} 40^{\prime} \mathrm{S} ; 73^{\circ} 2^{\prime} \mathrm{W}\right.$ ) y áreas adyacentes. Chile. Gayana (Misc.) 8: 1-56

Ahumada, R., Rudolph, A., Martínez, V (1983). Circulation and fertility of waters in Concepción Bay. Estuar. coast. Shelf Sci. 16: 95-105

Allen, K. R. (1949). Some aspects of the production and cropping of fresh waters. Rep. Sixth Sci. Congr. 1947. Trans. R. Soc. N. Z. 77: 222-228

Arcos, D. F., Wilson, R. E. (1983). Upwelling and the chlorophyll a distribution within Concepción Bay, Chile. Estuar. coast. Shelf Sci. (in press)

Benke, A. C. (1979). A modification of the Hynes method for estimating secondary production with particular significance for multivoltine populations. Limnol. Oceanogr. 24: $168-171$

Birklund, J. (1977). Biomass, growth and production of the amphipod Corophium insidiosum Crawford, and preliminary notes on Corophium volutator (Pallas). Ophelia 16: $187-203$

Brandhorst, W (1971). Condiciones oceanográficas estivales frente a la costa de Chile. Revta. Biol. mar. 14: 34-84 
Carrasco, F. D., Arcos, D. (1980). Estimación de la producción secundaria de Paraprionospio pinnata (Spionidae, Polychaeta) frente a Bahía de Concepción, Chile. Bolm. Inst. oceanogr., S. Paulo 29: 245-248

Carrasco, F. D., Gallardo, V A. (1983). Abundance and distribution of the macrobenthic infauna of the Gulf of Arauco, Chile. Int. Revue ges. Hydrobiol. 68 (in press)

Cederwall, H. (1977). Annual macrofauna production of a soft bottom in the Northern Baltic proper In: Keegan, B. F., Ceidigh, P. O., Boaden, P. J. S. (ed.) Biology of benthic organisms. Pergamon Press, Oxford, p. 155-164

Crisp, D. J. (1971). Energy flow measurements. In: Holme, N. A., McIntyre, A. D. (ed.) Methods for the study of the marine benthos. Blackwell, Oxford, p. 197-279

Gallardo, V. A. (1962). Descripción de una nueva especie de Ampelisca (Amphipoda). Gayana (Zool.) 7: 1-11

Gallardo, V. A. (1963). Notas sobre la densidad de la fauna bentónica en el sublitoral del Norte de Chile. Gayana (Zool.) 10: 1-15

Gallardo, V. A. (1968). Observaciones sobre la fauna bentónica del Golfo de Arauco. Boln Soc. Biol. Concepción 40: $145-160$

Gallardo, V. A. (1977). Large benthic microbial communities in sulphide biota under Peru-Chile subsurface countercurrent. Nature, Lond. 268: 331-332

Gunther, E. R. (1936). A report on oceanographic investigations in the Peru coastal current. 'Discovery' Rep. 13: $107-276$

Hamilton, A. L. (1969). On estimating annual production. Limnol. Oceanogr. 14: 771-782

Hastings, M. H. (1981). The life cycle and productivity of an intertidal population of the amphipod Ampelisca brevicornis. Estuar. coast. Shelf Sci. 12: 665-677

Hynes, H. B. N. (1961). The invertebrate fauna of a Welsh mountain stream. Arch. Hydrobiol. 57: 344-388

Hynes, H. B. N., Coleman, M. H. (1968). A simple method of assessing the annual production of stream benthos. Limnol. Oceanogr. 13: 569-573

Kanneworf, E. (1965). Life cycle and growth of the amphipod Ampelisca macrocephala Liljeborg from the Øresund. Ophelia 2: 305-318

Klein, G., Rachor, E., Gerlach, S. A. (1975). Dynamics and productivity of two populations of the benthic tube-dwelling amphipod Ampelisca brevicornis (Costa) in Helgoland Bight. Ophelia 14:139-159

Lapchin, L., Neveu, A. (1980a). The production of benthic invertebrates: comparison of different methods I. - Theoretical populations. Acta Oecologia, Oecol. Gener. 1: 307-322

Lapchin, L., Neveu, A. (1980b). The production of benthic invertebrates II. - Application to the benthos of the Nivelle river (Pyrénées-Atlantiques, France). Acta Oecologia, Oecol. Gener, 1: 359-372
Meléndez, R. H. (1981). Ecología trófica de algunos peces demersales entre Punta Tumbes y Pichidangui, Chile. Thesis, Universidad de Concepción, Chile

Menzie, C. A. (1980). A note on the Hynes method of estimating secondary production. Limnol. Oceanogr. 25: 770-773

Mills, E. L. (1967). The biology of an ampeliscid amphipod crustacean sibling species pair. J. Fish. Res. Bd Can. 24: 305-355

Mossman, D. (1978). Energetics of Corophium volutator. Ph. D. thesis, University of London.

Nelson, W. G. (1980). Reproductive patterns of gammaridean amphipods. Sarsia 65: 61-71

Neveu, A. (1977). Ecologie des larves d'Athericidae (Diptera, Brachycera) dans un ruisseau des Pyrénées-Atlantiques. II. Production; comparison de différentes méthodes de calcul. Ann. Hydrobiol. 8: 45-66

Peer, D. L. (1970). Relation between biomass, productivity, and loss to predators in a population of a marine benthic polychaete, Pectinaria hyperborea. J. Fish. Res. Bd Can. 27: $2143-2153$

Ricker, W. E. (1946). Production and utilization of fish populations. Ecol. Monogr. 16: 373-391

Rivera, P. (1968). Sinopsis de las diatomeas de la Bahía de Concepción, Chile. Gayana (Bot.) 18: 1-112

Sanders, H. L. (1956). Oceanography of Long Island Sound 1952-54. X. The biology of marine bottom communities. Bull. Bingham Oceanogr. Coll. 15: 345-414

SERNAP (1981). Servicio Nacional de Pesca, Chile. Anuario Estadistico de Pesca (unpublished)

Sheader, M. (1977). Production and population dynamics of Ampelisca tenuicornis (Amphipoda) with notes on the biology of its parasite Sphaeronella longipes (Copepoda). J. mar. biol. Ass. U. K. 57: 955-968

Sokal, R. R., Rohlf, F. J. (1969). Biometry, W. H. Freeman and Co., San Francisco

Van Dolah, R. F., Bird, E. (1980). A comparison of reproductive patterns in epifaunal and infaunal gammaridean amphipods. Estuar. coast. mar. Sci. 11: 593-604

Waters, T. F. (1977). Secondary production in inland waters. Adv. ecol. Res. 10: 91-164

Waters, T. F. (1979). Influence of benthos life history upon estimation of secondary production. J. Fish. Res. Bd Can. 36: $1425-1430$

Wildish, D. J. (1977). Biased sex ratios in invertebrates. In: Adiyodi, K. G., Adiyodi, R. G. (ed.) Advances in invertebrate reproduction, Vol 1. Peralam-Kenoth, Karivellur, India, p. 8-24

Wildish, D. J. (1982). Evolutionary ecology of reproduction in gammaridean Amphipoda. Int. J. Invertebr. Reprod. 5: $1-19$

Wildish, D. J., Peer, D. (1981). Methods for estimating secondary production in marine amphipoda. Can. J. Fish. aquat. Sci. 38: 1019-1026 